\title{
Norwegian rural jewelry traditions in the era of globalization
}

\section{Introduction}

The globalization process has led to universalness and sameness, but at the same time an increased appreciation of difference. 'The display of specific identities has become necessary to be visible in the universalness. They express our self-conception, but also how we want to be regarded by others. It reflects our ambitions towards the outside world both at a personal and social level. As potential tools for displaying these identities, local cultural traditions have increased in importance. They have become necessary ingredients in the societal communication process. ${ }^{2}$ The situation has enhanced the significance of personal adornment. With its symbolic function, jewelry constitutes an exceptionally powerful way of expressing them. The market for such items is flourishing.

In Norway the habit of wearing jewelry based on rural traditions constitutes a continuous tradition, which is even stronger than in the other Scandinavian countries. ${ }^{3}$ In the era of globalization it has increased, and the demand for such objects is substantial. The various professional groups within the designer community have responded according to their internal aesthetic preferences, which are not always congruent with those of the surrounding society. This has caused a discrepancy between demand and innovative design. ${ }^{4}$ The paper consists of an investigation of the historical background for this, seen at the backdrop of the situation in two widely different countries, India and Italy, where societal and market oriented innovation is playing a major role.

\section{The tradition and its development}

From medieval times jewelry has constituted an important part of the rural costume. (III. 1.) In social life it constituted symbolic requisites in family rituals. It was produced by local silversmiths, usually in the filigree technique. The silversmiths built up a personal reputation, and exceptionally fine pieces were highly esteemed. Their design was developed to a high level and in a way that was typical of Norway. 5 The innovativeness and originality of the objects is a fact that has recently been discovered. ${ }^{6}$

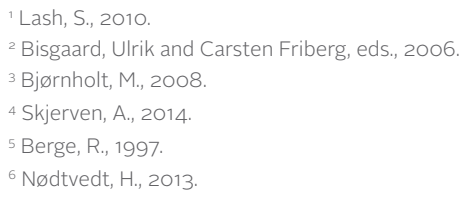


During the era of nation building objects that could symbolize national identity was in demand. Rural jewelry constituted an ideal source of inspiration for the city goldsmiths. This renewal was based on a living tradition, whereas such undertakings may rightfully be called "invented traditions" in other countries.7 Tostrup, one of the leading goldsmith firms in Oslo, followed the pattern of the famous firm Castellani in Rome, Italy, which applied traditions from local filigree work to renew their work. Tostrup looked to the same traditions in their own country. ${ }^{8}$ An excample of this is Norway's official gift for the wedding of Princess Victoria of Sweden in 1881, designed by Oluf Tostrup. It consists of a full bridal adornment that had a striking resemblance with rural bridalware. The products made in this style were sold to the rural market all over the country. ${ }^{9}$ The practice also led to an innovation of Tostrup's production for the urban bourgeoisie. "National jewelry", modern jewelry in the filigree technique inspired by rural adornment and fit for urban dressing, became a great vogue.

During the golden age of Scandinavian Design in the post war era, the foreign tastemakers particularly esteemed the unique combination of modernity and regional traditions. ${ }^{10}$ In 1951 Grete Prytz Kittelsen at Tostrup designed the brooch "With dots", which was meant to be a modern folk brooch. ${ }^{11}$ The shape was based on the main brooch of the rural adornment, but was serially produced and made for modern urban outfits. Her design was too avant-garde to be a commercial hit, but sold moderately to the élite segment of the market.

During Postmodernism inspiration from rural traditions had a flowering period. There was a trend of renewing folk tradition which was called "Neotradition".12 Some used the tradition to create an ironic play with a style of previous times, and to make critical comments on contemporary society. Konrad Mehus was educated as a goldsmith, craft artist and sculptor. One of his most significant contributions is the "Carrot brooch" from 1991. (III. 2.) Its shape was taken from a special category of heart shaped brooches which were used as engagement gifts, decorated with symbols of love. In Mehus' "Carrot brooch" the heart had been transformed to a phallus-like carrot, and the "leaves" were made of painted wood. The ironic "anti folk brooch" was well received by professionals and other particularly interested. ${ }^{13}$

\section{The present situation}

The main tendency in avant-garde jewelry in the late 2oth and early 21st century has been to achieve inclusion the sphere of fine art as opposed to that of decorative art. An example is the development of the Grande Dame of modern Norwegian jewelry, Tone Vigeland. Since the 1990 s she has abandoned making jewelry in order to explore space in the form of large minimalistic art installations. ${ }^{14}$

Many of today's designers with education from the art schools have followed this path. They are concerned with artistic expression in a global professional setting without regard 
to personal adornment or own national origin. The arenas of presentation and discourse are art exhibitions. Their market consists of museums and collectors. Others stick to making art oriented jewelry, with no relation to the rural traditions. One of the exponents is French-Norwegian Anne Léger, who makes unique pieces based on dream-like visions. Because of her background she has an outsider's perspective of the situation. ${ }^{15}$ She admires the rural silversmiths' traditions, but as a foreigner she would not use them in own work. Her Norwegian colleagues' neglect of them is explained by the fact that they are not taught at the art schools. She regards the general popularity of such objects by their creation of recognition and their representation of national culture and history. ${ }^{16}$

Although the traditions have been almost forgotten in the avant-garde and art oriented circles, they are being painstakingly taken care of by a few outsiders. One of them is Hilde Nødtvedt, who is educated both as a goldsmith and an ethnologist. She has also studied ancient Italian filigree work and the work of Castellani. She is making pieces that are in accordance with historical research. But like the rural silversmiths, she always adds a personal touch. ${ }^{17}$ In this way her pieces simultaneously represent a link to the past and to contemporary aesthetic values. Her most extensive undertaking is an adornment for a reconstruction of an East Telemark wedding costume. (III. 3.) Nødtvedt's customers consist of a handful of particularly interested people. ${ }^{18}$

The low focus on rural traditions among the designers is caused by the neglect of them in higher education. However, alternatives are emerging in the regional centers of the old traditions. In 2005 The University of Aust-Agder planned a bachelor education in folk jewelry, which was never realized. ${ }^{19}$ Telemark University College has taken up the challenge by establishing a Bachelor and Master degree in folk art. The interest for it is increasing. ${ }^{20}$

\section{In a global perspective}

The situation in Norway stands in contrast to that in many other countries. It is a world-wide trend that local jewelry traditions are being regarded as a valuable source of inspiration for contemporary design, due to their ability to display personal and national identities. In the so called third world, they are used as symbols of their growing independence and increasing international status. This is taking place in many of the growing economies in these countries. One of the most significant examples is India, where there is a systematic use of them. In the Western hemisphere their commercial value is being utilized, particularly in countries where high end fashion industry plays a significant role. Italy is a clear example of this.

In India the new generation of designers are exponents of what has been coined as "artistic nationalness". Their domestic customers consist of the upper and educated classes, who prefer products that express "Indianness". Strongly supported by the Indian

\footnotetext{
${ }^{12}$ Opstad, J.-L., 1988

${ }^{13}$ Veiteberg, J., 2012.

${ }^{14}$ www.galleririis.com

15 Halén, W., 2012.

${ }^{16}$ Léger, A., 2013.

${ }_{17} \mathrm{~N} ø \mathrm{dtvedt}, \mathrm{H} ., 2013$.

${ }^{18}$ Nødtvedt, H., 2013.

${ }^{19}$ Haugen, T. 2012.

20 Johnsrød, A.M., 2013.

${ }^{21}$ Kuldova, T., ed., 2013.
} 
government and commercial interests their work is also promoted towards the fashion market of the outside world. ${ }^{21}$ This is not only the case in commercial design, but also in art oriented jewelry. Among its leading exponents is the designer duo Preti Gupta and Vivek Prasad. Their experimental jewelry have shapes that are reminiscent of forms found in Indian nature and are put together by ways of ancient joinery techniques. Their work is highly esteemed in the world of international avant-garde jewelry. ${ }^{22}$

As a country which jewelry design has made special impact in Norway, the situation in Italy is of particular interest. Its strong innovative traditions with many regional variations have inspired many of its present designers. Jewelry has recently conquered the field of fashion design far beyond the traditional function as discreet accessories. They are now playing a role as symbols of attitudes, values and life styles. In the collections of Dolce \& Gabbana, one of the world's leading fashion brands, jewelry has become an important ingredient. The brand is expressing a female identity that is based on the image of the Sicilian woman. The firm launched its first separate jewelry collection in 2009.

It consists of hand-made objects in precious materials. ${ }^{23}$ The filigree based technique and the shapes are based on Sicilian Baroque jewelry. ${ }^{24}$ In its fashion collections large and colourful versions in cheaper materials are playing a major role. As an expression of feminine beauty connected to family values and local culture, but at the same time modernity, the jewelry has become a hit at the international market, including Norway ${ }^{25}$. The different practices in India, Italy and Norway reflect their role and ambitions on the global scene. As a rising star on the sky of global powers India has made a deliberate choice to make use of its pre Colonial traditions. It has created a national brand that displays modern "Indianness", which works both domestically and internationally. Italy is continuing its historic position as an exporter of its classical traditions, now with a new focus on the local aspects.

Norway is situated in the periphery of global power and influence. In this way it has been able to maintain its traditions, but still mainly for domestic use. The country is becoming increasingly involved in undertakings in other parts of the world, and the Norwegian government has become aware of the advantage of having a strong national brand. Investigations have revealed a vague national profile. ${ }^{26}$ Now steps are taken to improve it. ${ }^{27}$ In this situation local traditions constitute a possible tool. ${ }^{28}$

In this way the cultural heritage of the rural silversmith works have become of importance also at a national and global level. There is a need to rejuvenate the traditions and use them to display and discuss contemporary identities. This demands a change of attitude and competence in the designer community. The situation has started to change, as the world of art is becoming increasingly engaged in interacting directly with the audience. ${ }^{29}$ The renewed recognition of crafts as an artistic tool has also led to a higher estimation

\footnotetext{
22 Jewel Book 2012/13.

${ }^{23}$ www.dolcegabbana.com/accessories.jewellery/

${ }^{24}$ Natale, M.C. di, 2008.

${ }_{25}$ Interview with Anne Birgitte Melander, owner and manager of the only store in Norway that is selling the brand. Melander, A.B., 2013.

${ }^{26}$ Norwegian Ministry of Foreign Affairs, 2009.

${ }^{27}$ Utenriksdepartementet, s.n.

${ }^{28}$ E-mail of 10.01.2004 from Signe Ihlen Tønsberg,, Ministry of Norwegian Policy.

${ }^{29}$ An excample is Marina Abramowitz' invitatation to follow her example of performing Edward Munch's «Scream» in the Ringnes Sculpture Park in Oslo in the summer of 2013.
} 
of its heritage..$^{30}$ Additionally, the traditions and the production techniques have to be included in higher education. In the global world of competing identities the contribution of innovative and highly skilled jewelry designers is needed.
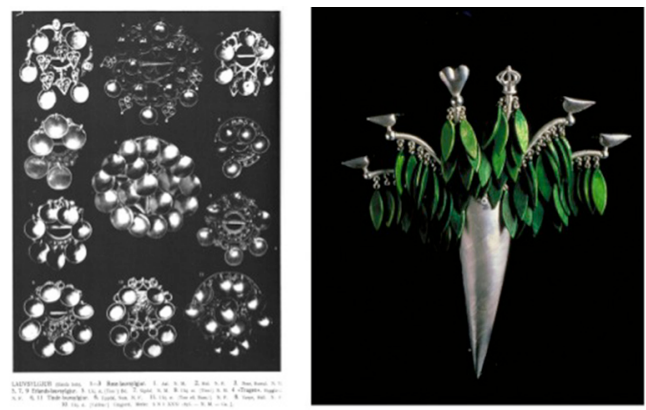

Figure 1 (left).

LAUVSYLGJUR

jewellery

Figure 2 (right)

K. Mehus:

Gulrotsøljen

1991

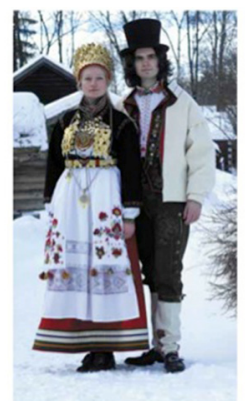

Figure 3 .

H. Nødtvdt:

Bunadsølv

2000-t.

\section{References}

Adamson, Glenn. Thinking through Craft. Oxford: Berg, 2007.

Berge, Rikard. Norskt Bondesylv. Skien: Fylkesmuseet for Telemark og Grenland, 1997.

Facsimile of 1st ed. 1925.

Bisgaard, Ulrik and Carsten Friberg, eds., DetÆEœstetiskes Aktualitet. København:

Multivers, 2006.

Bjørnholt, Margunn. "Hvorfor er Folkedrakt så viktig i Norge og marginal I Nabolandene?"

Nordisk Kulturpolitisk Tidskrift 8(2) 2008, 34-44.

Halén, Widar, ed. From the Coolest Corner. Nordic Jewellery.Stuttgart: Arnoldsche, 2012.

Haugen, Tarjei. E-mail 02.04.2013.

Hobsbawm, Eric and Terence Ranger, eds. The Invention of Tradition. Cambridge:

University of Cambridge Press, 1983.

Jewel Book: International Annual of Contemporary Jewel Art 2012/13. Oostkamp:

Stitcheny Kunstboek, 2013.

Johnsrød, Arne Magnus. E-mail 06-09.2013.

Kielland, Thor. Om Gullsmedkunst i Hundre År: J. Tostrup 1832-1932. Oslo: Grøndahl, 1932. Kuldova, Tereza, ed. Fashion India: Spectacular Capitalism. Oslo: Akademika, 2013. 
Lash, Scott. Intensive Culture: Social Theory, Religion and Contemporary Capitalism. London: Sage, 2010.

Legér, Anne. E-mail 07.08.2013

Melander, Anne Birgitte. Interview 18.12.2013.

Natalie, Maria Concetta di. Gioielli di Sicilia. 2nd Ed. Palermo: Placcovio, 2008.

Norwegian Ministry of Foreign Affairs. Improving Norway's reputation. Oslo: The Ministry, 2009

Nødtvedt, Hilde. Interview 19.12.2013.

Opstad, Jan- Lauritz. Neo-tradisjon: Norske Kunsthåndverkere I Midt-Norge. Trondheim: Nordenfjeldske Kunstindustrimuseum, 1988.

Skjerven, Astrid. Goodwill for Scandinavian Design: Lunningprisen 1951-70. Oslo: Universitetet, 2001. PhD dissertation.

Skjerven, Astrid. "The Jewellery Artist." Gilje, Karianne, ed. Grete Prytz Kittelsen: Enamel and Deesign. New York: Gordon, 2011.

Tønsberg, Signe Ihlen. E-mail 10.01.2014.

Utenriksdepartementet. Håndbok i strategisk kommunikasjon og omdømme. Oslo:

Departementet, s.n.

Veiteberg, Jorunn, ed. Konrad Mehus: Form følgjer Fiksjon: Smykke og Objekt / Form follows Fiction: Jewelry and Objects. Stuttgart: Arnoldsche, 2012.

www.dolcegabbana.com/accessories.jewellery/

www.riis.com 